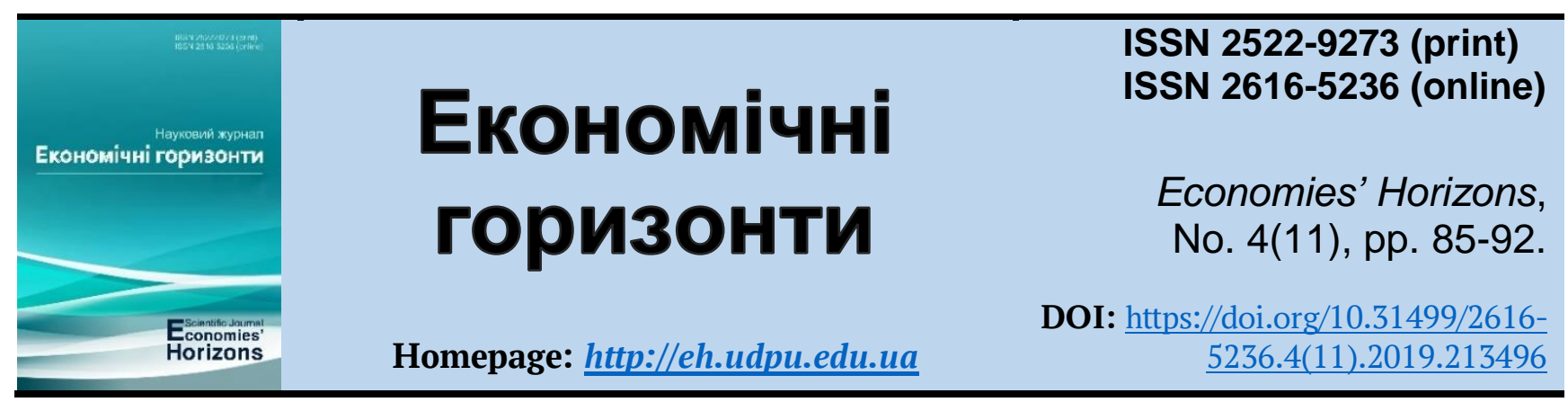

UDC 336.13.14.025

\title{
Instruments of state regulation and fiscal mechanisms of financial and investment support and development of agricultural enterprises
}

\author{
Olexandr M. Kondrashov ${ }^{1}$, Doc. Pub. Adm., Associate Professor \\ Vitalina V. Malyshko², Can. Ec. Sc., Associate Professor
}

Received: 25 October 2019 Accepted: 30 November2019
Kondrashov, O. M. and Malyshko, V. V. (2019), "Formation of local budgets in the conditions of administrative-territorial reform in Ukraine", Economies' Horizons, no. 4(11), pp. 85-92, doi: https://doi.org/10.31499/2616-5236.4(11).2019.213496

Abstract. The purpose is to determine the features of the formation and development of local budgets in terms of administrative-territorial reform. Methods used in the research process: monographic, historical, system-structural analysis and synthesis, statistical-economic and other research methods. $R e-$ sults. Peculiarities of formation and development of local budgets are revealed and their content and structure are determined. The most significant problems in the field of local budget formation in Ukraine are pointed out. The assessment and analysis of the effectiveness of the formation and directions of development of local budgets for the period 2018-2019 are carried out. Formation and development of local budgets in terms of administrative-territorial reform and decentralization of power should be carried out in stages, purposefully and consistently. They should be based on the results of monitoring the main indicators and indicators of the financial and economic situation. This will avoid mistakes, irrational costs, so these issues remain quite controversial. The formation of local budgets and the efficient use of their financial resources are the priorities of administrative-territorial reform and decentralization of power in Ukraine. They should become tools that will create such conditions for transformation, where each territory (community) will be an independent and full-fledged owner of resources for development and growth. Independent local budgets must fully satisfy the functions and powers of local authorities. Therefore, the financial decentralization of the united territorial communities is an important lever in establishing them as independent and financially independent economic entities of the country and its regions. Practical meaning. The article has practical significance for local governments, city and district councils, higher education institutions. Prospects for further research. Ways of forming financial independence of local self-government bodies in the conditions of decentralization of power and other measures of administrative-territorial reform.

Keywords: local budgets, administrative-territorial reform, decentralization, financial resources, taxes, monitoring, local self-government, territorial communities, efficiency, management.

\footnotetext{
${ }^{1}$ Association of Taxpayers of Ukraine; Member of the Board; ORCID ID: https://orcid.org/0000-0003-22546605; e-mail: kondrashov_o@ukr.net

${ }^{2}$ Hryhorii Skovoroda Pereiaslav-Khmelnytskyi State Pedagogical University; Associate Professor at the Department of Finance, Accounting and Taxation; ORCID ID: https://orcid.org/0000-0003-2254-6605; e-mail: natali.novak74@ukr.net
} 
JEL Classification: E60, E62, E63, E69.

Number of references: 15; number of tables: 0; number of figures: $\mathbf{0}$; number of formulas: $\mathbf{0 .}$

\title{
Формування місцевих бюджетів в умовах адміністративно- територіальної реформи в Україні
}

\author{
Олександр Миколайович Кондрашов ${ }^{1}$, д. держ. упр., доцент \\ Віталіна Валеріївна Малишко ${ }^{2}$, к. е. н., доцент
}

Стаття надіŭшла: 25.10.2019
Cтаття прийнята: 30.11.2019

Анотація. Метою статті є визначення особливостей формування та розвитку місцевих бюджетів в умовах адміністративно-територіальної реформи. Методологія. У досліджені застосовані загальнонаукові методи, зокрема: монографічний, історичний, системно-структурного аналізу та синтезу, статистико-економічні та інші методи дослідження. Результати. Виявлено особливості формування та розвитку місцевих бюджетів та визначено їх зміст і структуру. Вказано на найбільш суттєві проблеми у сфері формування місцевих бюджетів в Україні. Здійснено оцінку та аналіз ефективності формування й напрямів розвитку місцевих бюджетів за період 2018-2019 pр. Формування та розвиток місцевих бюджетів в умовах проведення адміністративнотериторіальної реформи й децентралізації влади має здійснюватися поетапно, цілеспрямовано та послідовно. Вони мають спиратися на результати моніторингу основних індикаторів і показників фінансово-економічної ситуації. Це дозволить уникнути помилок, нераціональних витрат, тому ці питання залишаються досить дискусійними. Формування місцевих бюджетів та ефективність використання їх фінансових ресурсів є пріоритетними завданнями адміністративно-територіальної реформи й децентралізації влади в Україні. Вони мають стати інструментами, які створять такі умови перетворень, де кожна територія (громада) буде самостійним і повноправним господарем ресурсів розвитку і зростання. Самостійні місцеві бюджети в повній мірі мають задовольняти виконання функцій та повноважень місцевих органів влади. Тому фінансова децентралізація об’єднаних територіальних громад є вагомим важелем в утвердженні їх як самостійних і фінансово незалежних суб'єктів економіки країни та ï регіонів. Практичне значення. Стаття має практичне значення для органів місцевого самоврядування, міських та районних рад, закладів вищої освіти. Перспективи подальших досліджень. Шляхи формування фінансової незалежності органів місцевого самоврядування в умовах децентралізації влади й інших заходів адміністративнотериторіальної реформи.

Ключові слова: місцеві бюджети, адміністративно-територіальна реформа, децентралізація, фінансові ресурси, податки, моніторинг, місцеве самоврядування, територіальні громади, ефективність, управління.

Кількість джерел: 15; кількість таблиць: 0; кількість рисунків: 0; кількість формул: 0.

\section{Introduction.}

Local budgets have a special place in the budget system of any country. They determine the financial basis of local communities. In order for local budgets to become financially independent and efficient, it is necessary to clearly divide competencies between central government, regional and local self-

\footnotetext{
${ }^{1}$ Асоціація платників податків України, член Правління; ідентифікатор ORCID: https://orcid.org/00000003-2254-6605; e-mail: kondrashovo@ukr.net

${ }^{2}$ Переяслав-Хмельницький державний педагогічний університет імені Григорія Сковороди; доцент кафедри фінансів, обліку і оподаткування; ідентифікатор ORCID: https://orcid.org/0000-0001-8906-9060; e-mail:malyshkovitalina@gmail.com
} 
government bodies and gradually move to decentralization of state and local finances.

\section{Literature review.}

Research of theoretical and practical aspects of formation and development of budget policy in the conditions of administrativeterritorial reform and decentralization of power in Ukraine is devoted to scientific works: O. Suntsova (2009), L. Panasiuk (2011), T. Voitovych (2012), I. Haba (2014), I. Irtyshchevaand and I. Kramarenko (2014), N. Yevtushenko (2015), I. Lintur (2015), Y. Nabatova and T. Us (2015), M. Ihnatenko and L. Marmul (2017), M. Stehnei, I. Irtyshcheva, K. Khaustova and Y. Boiko (2017), M. Ihnatenko (2019), O. Mandych, I. Naumenko and I. Romaniuk (2019) and other famous scientists. However, the establishment of stages of their operation, major changes, justification of development prospects in the context of decentralization requires further theoretical and practical developments.

\section{Methodology.}

The theoretical and methodological bases of the study are scientific works formation of local budgets in the conditions of administrative-territorial reform. The following research methods are used to achieve the purpose of the work: monographic, historical, systemstructural analysis and synthesis, statisticaleconomic and other research methods.

\section{Research objectives.}

The main purpose is to determine the peculiarities of the formation and development of local budgets in terms of administrative-territorial reform.

\section{Results and discussions.}

It is established that until 2015 Ukraine had a system of inter-budgetary relations based on a centralized model of budget federalism, the main features of which were inherited from the administrative-command system of government. Centralization of fiscal functions (Yevtushenko, 2015). This manifested itself in their dependence on the state budget due to maintaining the priority of the normative method of distribution of budget funds and the high share of transfers in local budget revenues, which negatively affected the development of inter-budgetary relations in a market economy. Since 2015, as a result of changes in budget and tax legislation, for the first time since independence, an attempt has been made to decentralize the system of intergovernmental relations. The Law "On Amendments to the Budget Code of Ukraine on the Reform of Intergovernmental Relations" was adopted on December 28, 2014 to promote budget decentralization.

To assess the degree of fiscal decentralization use the indicator of the share of regional (local) levels of government in revenues and expenditures of the consolidated budget. An indicator of a high level of decentralization is the share of local expenditures at more than $45 \%$ of national expenditures, medium - 30$45 \%$, and low - less than 30\% (Nabatova and Us, 2018). According to the Budget Code, there have been significant changes in the approaches to the formation of spending powers, which are delegated exclusively to the level of the city of regional significance, the district level and the level of territorial communities, which will be combined. Starting in 2015, local budgets will receive the following new types of transfers: education subvention, training subvention and medical subvention.

The first results of budget decentralization are as follows: at the local level, village councils can provide for themselves. But this should not be a reason to refuse to unite territorial communities. Because the united territorial communities (UTCs), whose budgets will be equated to the budgets of cities of regional significance and districts, and, in addition to these taxes, will receive another $60 \%$ tax on personal income and other income. In addition, the association of communities will optimize expenditures for the maintenance of the administration, and most importantly - will significantly improve the quality of administrative and social services to the population (Ihnatenko, 2019).

Today, the constant desire for independence of local budgets, further development and strengthening of local self-government 
requires greater financial independence and viability of local authorities. The level of development of the country and the growth of the welfare of the population directly depend on the growth of a strong local government, which is able to provide adequate funding for educational, cultural, health care, solve problems and defend the interests of the population, and so on. The operation of the institution of local self-government is the norm of democratic development of the country, which provides for broad autonomy of the population in addressing issues of self-government development. All this is a fundamental condition for the decentralization of budget funds, as one of the models of inter-budgetary relations (Suntsova, 2009).

In terms of the number of local budgets, Ukraine is second only to France among European countries. The current system of local budget formation has a number of significant shortcomings: a high degree of concentration of financial resources in the state budget, which reduces the importance of regional and local budgets in solving vital tasks for the population; low share of fixed revenues (tax payments) in the structure of revenues to regional and local budgets; almost annual change of types of taxes credited to local budgets; lack of uniform and fairly stable standards (for example, for several years) of deductions from national taxes to local budgets.

At the same time, the main problem of financial support of local authorities is the inefficient use of received transfers on the ground, which, in turn, negatively affects the socioeconomic development of regions. In general, among the problems in local budgeting in Ukraine the most significant are: instability income base; secondary local taxes and fees compared to national, insufficient funding from the state budget; the presence of local taxes, the administration costs of which exceed the revenues from them; a small list of local taxes and fees compared to other countries; insignificant fiscal role of local taxes and fees and, as a consequence, their low share in local budget revenues (Voitovych, 2012).

Therefore, in order for local budgets to really become the basis for the financial independence of local government, a set of interrelated measures is needed. First, it is necessary to gradually move to decentralization of public finances. The main condition for such decentralization is a clear division of competencies between central authorities and regional and local governments. Secondly, it is necessary to give local governments the opportunity to independently establish a list of local taxes and fees and their rates to the extent and adequacy of their functions.

Another source of replenishment of local budgets could be local loans, but, unfortunately, in Ukraine they have not become properly distributed, typical of European countries (Panasiuk, 2011). The process of decentralization expands the opportunities for the development of UTCs and their economic independence. Decentralization, and as a consequence of strengthening the financial capacity of the budgets of the UTCs, provide an opportunity for their sustainable development.

In addition, an important condition for solving the problem of strengthening the revenue base of local budgets is to expand the rights of local governments in the field of taxes and fees, as well as creating a multi-channel budgeting system, based on which each level of the budget system must have its own revenues. These revenues should be sufficient to support the functions and responsibilities assigned to a particular level of government.

Subject to the adoption of amendments to the Budget and Tax Codes, local communities will be able to form their own budgets without waiting for the formation of the central one, as is done today. Revenue sources, the base of administration and granting the right to local governments to regulate the rates of local taxes and fees within the limits set by the Tax Code are expanding.

Another innovation should be to give budgetary institutions the right to choose where to serve - in the treasury or a commercial bank (Lintur, 2015). At the present stage, Ukraine is steadily focusing its efforts on the implementation of the European integration course, the implementation of international 
legal obligations, including the development of local and regional democracy. Further democratization of society, decentralization of power on the basis of subsidiarity have been and remain the priorities of Ukraine. An important role in these processes is played by reforming local self-government and territorial organization of power in accordance with the European Charter of Local Self-Government (Tarnai, 2015).

This was confirmed by the definition in the program documents of the President, Government and Verkhovna Rada of Ukraine of priorities, including decentralization of power, transfer of financial resources and strengthening the material and financial base of local governments, meeting the interests of citizens in all spheres of life in relevant areas, services to the population, coordination of interests of the state and territorial communities. The implementation of the reform was started on the basis of the Concept of Reforming Local SelfGovernment and Territorial Organization of Government, the Government's Action Program, the 2020 Strategy of the President of Ukraine and the relevant plan for their implementation.

The first step towards the reform of local self-government was the task of financial decentralization, in particular the transfer of additional budgetary powers and stable sources of income for local self-government to their implementation; stimulating territorial communities to unite and transition to direct interbudgetary relations with the state budget with appropriate resources at the level of cities of regional significance, etc.

The next important step was the adoption of the Law of Ukraine "On Voluntary Association of Territorial Communities" and the Methodology for Forming Capable Territorial Communities, approved by the Cabinet of Ministers of Ukraine in April 2015 to introduce legal bases for forming capable territorial communities by increasing their financial and economic capacity (Ihnatenko and Marmul, 2017). Budget decentralization in Ukraine in the form of increasing the powers of local authorities on the resources of local budgets has been going on for several years and each time is declared in the Main Directions of Budget Policy.

In the reforming system of decentralization of budget resources, the sources of filling local budgets have been expanded due to:

1) transfer of revenues from the state budget $(100 \%$ of the fee for the provision of administrative services, $100 \%$ of the state duty, $10 \%$ of the profit tax of enterprises of the private sector of the economy);

2 ) introduction of excise tax on the sale of excisable goods (beer, alcoholic beverages, tobacco products, petroleum products) by retail business entities at the rate of 5 percent of the value of goods sold;

3) expansion of the real estate tax base by including in the taxation of this tax commercial (non-residential) property and cars with a large engine capacity;

4) increase of the norm of enrollment in local budgets of the ecological tax from $35 \%$ to $80 \%$ (Kaziuk, 2017).

If the reforms in the tax system can be attributed to the positive moments, then the change of transfer policy provides a "bright future" only for economically strong territories. Both processes will take place in parallel and cannot be carried out at different times. It is no secret that the vast majority of regions of Ukraine are subsidized and this may mean that local self-government is not yet ready to move to self-sufficiency. Changing the tax system plays an important role in shaping local budgets, but regions must earn not only formally, but also create or restore existing sources of livelihood - revenues and revenues of local budgets, which can provide only the real economy.

One of the important changes to the Budget Code of Ukraine was the change, which provides for the possibility of keeping the savings at the end of the reporting period in the accounts of local governments and use them next year. In this way, local officials were motivated to save. Previously, anything had to be used and debited by the end of the 
year, but now this practice should be a thing of the past. Another important innovation is the ability to place temporarily free funds of the special fund of local budgets in commercial banks. On the one hand, this solves the problem of delayed payments from the Treasury, on the other - deprives local governments of the opportunity to receive interest-free loans to cover temporary cash gaps in local budgets (Haba, 2014).

Analysis of the implementation of local budgets for January-September 2019 showed that the total amount of revenues to local budgets (including all types of transfers) amounted to UAH 416.9 billion, which is UAH 3.2 billion more than in the same period of 2018. Of this amount, revenues of the general fund amount to UAH 387.8 billion (+3.5 UAH billion), special - UAH 29.1 billion (-0.3 UAH billion) During January-September 2019, revenues to the general fund of local budgets of Ukraine (excluding intergovernmental transfers) amounted to UAH 199.7 billion, which is $75.6 \%$ of the approved annual plan for subject to change (Decentralization provides opportunities, 2019).

Compared to the same period in 2018, the nominal growth of revenues is UAH 31.9 billion or $+19.0 \%$ (according to the State Statistics Service, the price index for January-September 2019 to the corresponding period of 2018 is $108.8 \%$ ), but compared to last year's indicators, the growth rate of income decreased by 5.2 percentage points (In JanuarySeptember 2018, the increase in revenues compared to 2017 was $24.2 \%$ ). The budget of the city of Kyiv (general fund without transfers) for 9 months of 2019 received UAH 32.9 billion, which is $16,5 \%$ of the total amount of revenues of all local budgets of Ukraine. Revenues of the budget of the city of Kyiv (excluding transfers) are almost equal to the revenues of the consolidated budgets of districts (UAH 34.9 billion) (Decentralization provides opportunities, 2019).

In the structure of local budget revenues, the largest share is occupied by the personal income tax $-59.8 \%$ of the total revenues of the general fund of local budgets (or UAH 119.3 billion). Compared to January-September 2018, tax revenues increased by UAH 21.2 billion, or by $21.6 \%$. The main factors influencing the growth of PIT revenues are the increase in the minimum wage $(+12.1 \%$ by 2018$)$ and the increase in the average monthly wage by $19.4 \%$ (up to UAH 10,260) compared to the corresponding period of 2018).

The second largest source of revenue for local budgets is the payment for land, which is related to the property tax, which is a local tax. In the structure of revenues of the general fund of local budgets, the fee for land is $12.5 \%$. In the reporting period, UAH 25 billion was paid to local budgets. payments for land (namely land tax and rent), which is $22.2 \%$ (or UAH 4.5 billion) more than the revenues of the same period in 2018. Among other factors, the growth of revenues from land fees was influenced by the abolition from the beginning of 2019 of preferential taxation of land plots provided for railways (according to estimates, in 2019 PJSC “Ukrzaliznytsia” must pay UAH 4.2 billion in fees to local budgets for land, compared to UAH 1.2 billion paid during 2018).

A significant share in the structure of local budgets belongs to the receipt of a single tax. In the analyzed period, it accounts for $12.4 \%$ of revenues of the general fund of local budgets. The volume of single tax revenues for 9 months of 2019 amounted to UAH 24.7 billion, which is $22.0 \%$ (or UAH 4.5 billion) more than the revenues of the same period last year. It should be noted that UAH 18.2 billion was transferred to local budgets by individual entrepreneurs. single tax (or $73.8 \%$ of its total), legal entities paid UAH 3.7 billion (14.9\%), agricultural producers - UAH 2.8 billion (11.3\%).

Regarding excise tax revenues, during 9 months of 2019 local budgets received UAH 10.2 billion excise tax, including: UAH 5.6 billion - in the form of deductions from the state budget of part of the excise tax on fuel produced in Ukraine and imported into the customs territory of Ukraine (13.44\%), which is by UAH 210.3 million. less than for the same period in 2018, UAH 4.6 billion - from the sale of alcoholic beverages and tobacco products 
by retail trade entities, which is only by $3.9 \%$ or by UAH 173.5 million. more than in the same period of 2018 (Decentralization provides opportunities, 2019).

In 2019, 806 united territorial communities had direct inter-budgetary relations with the state budget (including 24 cities of regional significance in which the accession took place). In January-September 2019, revenues of the UTC general fund (excluding transfers from the state budget) amounted to UAH 28.1 billion, which is $14.1 \%$ of the total revenues of all local budgets of Ukraine.

Compared to the first half of the year, the share of UTC budgets increased by $0.4 \%$ (from $13.7 \%$ to $14.1 \%$ ). Revenues from personal income tax amount to UAH 16.3 billion or $57.8 \%$ of the revenues of the general fund of UTC budgets. Local taxes and fees make up $31.4 \%$ of the amount of UTC revenues or UAH 8.8 billion. Among 806 budgets in 9 UTCs the share of local taxes and fees is less than $10 \%$ of the general fund revenues, in 74 budgets up to $20 \%$, in 243 budgets - up to $30 \%, 516$ budgets - up to $40 \%, 712$ budgets - up to $50 \%$. In 94 UTC budgets, the share of local taxes and fees is over $50 \%$ of the general fund revenues.

For 665 UTCs, which had direct intergovernmental relations in 2018 (for which there is a correct comparative base), revenues in January-September this year amounted to UAH 17.4 billion, which is $19.3 \%$ more than last year. In the structure of revenues of the general fund 665 UTC the share of personal income tax is $56.8 \%$, its revenues amounted to UAH 9.9 billion. The share of local taxes and fees in the structure of UTC revenues is $32.7 \%$ or UAH 5.7 billion. It should be noted that among the 141 UTCs formed in 2018, there are 24 cities of regional significance that received personal income tax even before joining them communities (Decentralization provides opportunities, 2019).

The total population living in the united territorial communities is $8,315.3$ thousand people. In 141 UTCs, in which the first elections took place in 2018 (including accession), the total number of inhabitants is 2,694.6 thousand people, of which 1,793.1 thousand people (66.5\%) live in 24 cities of regional significance, in which the accession of territorial communities took place. The total expenditures of local budgets in January-September 2019 amounted to UAH 387.3 billion, which is UAH 4.4 billion less than the amount of expenditures made for the same period in 2018. Of this amount, expenditures of the general fund in the current year amounted to UAH 319.2 billion, which is UAH 8.4 billion (or 2.6\%) less than last year (Decentralization provides opportunities, 2019).

Expenditures amounting to UAH 40.1 billion were made from the general fund of UTC budgets, including: UAH 25.5 billion was directed to the accrued salary. (63.6\% of the total amount of expenditures), for the payment of utilities and energy - UAH 2 billion (5\%) During January-September 2019, local budgets received transfers from the state budget in the total amount of UAH 200.2 billion, in particular: basic subsidy - UAH 7.8 billion (including UTC budgets received UAH 2.1 billion, or $26.9 \%$ of the total amount of the basic subsidy), medical subvention - UAH 41.3 billion (including UTC budgets received UAH 4.1 billion, or $10 \%$ of the total amount of the subvention), education subvention - UAH 52.6 billion (including UTC budgets received UAH 12.0 billion, or $22.8 \%$ of the total amount of the subvention); (including UTC budgets received UAH 0.5 billion, or $17.9 \%$ of the total amount of the subvention), subventions for social protection of the population - UAH 64.2 billion, subventions for the formation of UTC infrastructure - 1.4 UAH; subvention for road maintenance - UAH 11.3 billion and UAH 5.1 billion was transferred to the state budget from local budgets. reverse subsidy, including UTC budgets transferred UAH 0.8 billion, or $15.6 \%$ of its total (Mandych, Naumenko and Romaniuk, 2019).

\section{Conclusions.}

The formation of local budgets and the efficient use of their financial resources are the priorities of administrative-territorial reform and decentralization of power in Ukraine. 
They should become tools that will create such conditions for transformation, where each territory (community) will be an independent and full-fledged owner of resources for development and growth. Independent local budgets must fully satisfy the functions and powers of local authorities. Therefore, the financial decentralization of the united territorial communities is an important lever in establishing them as independent and financially independent economic entities of the country and its regions.

\section{References}

Decentralization provides opportunities (2019), "Local budgets: Experts analysed results for 9 months of 2019", available at: https://decentralization.gov.ua/news/11861 (Accessed 20 October 2019)

Haba, I. M. (2014), “Decentralization - some pros and cons”, District Info, no. 1, pp. 5-14.

Ihnatenko, M. M. (2019), "Financial and investment activity of agrarian enterprises in the format of social responsibility”, Agrosvit, vol. 8, pp. 3-6. doi: https://doi.org/10.32702/2306-6792.2019.8.3

Ihnatenko, M. M. and Marmul, L. O. (2017), “Accounting, assessment and diagnosis of financial and economic results of activity in the strategic management of enterprises and organizations”, Eastern Europe: Economy, Business and Management, no. 6(11), pp. 115-118, available at: http://easterneurope-ebm.in.ua/journal/11 2017/24.pdf (Accessed 20 October 2019)

Irtyshcheva, I. O. and Kramarenko, I. S. (2014), "Investment attractiveness of the economy: inter-regional asymmetries", Regional Economy, no. 2(72), pp. 84-95.

Kaziuk, Ya. (2017), "Financial decentralization and budgets of the first 159 united communities in detail” , available at: https://decentralization.gov.ua/en/news/5244 (Accessed 20 October 2019)

Lintur, I. V. (2015), "Possibilities of optimization of formation of revenues of local budgets in the conditions of decentralization”, Hlobalni ta natsionalni problemy ekonomiky, [Online], vol. 4, pp. 853-855, available at: http://global-national.in.ua/archive/4-2015/181.pdf (Accessed 20 October 2019)

Mandych, O. V., Naumenko, I. V. and Romaniuk, I. A. (2019), "Formation of commodity distribution policy in integrated structures”, Actual problems of innovative economy, no. 4, pp. 83-87. doi: https://doi.org/10.36887/2524-0455-2019-4-14

Nabatova, Y. O. and Us, T. V. (2015), "Formation of local budgets in conditions of decentralization of financial resources", Efektyvna ekonomika, [Online], no. 5, available at: http://www.economy.nayka.com.ua/?op=1\&z=4100 (Accessed 20 October 2019)

Panasiuk, L. V. (2011) "Improving the mechanism of formation of financial resources of local authorities taking into account the world experience", Economy and state, no. 1, pp. 46-50.

Stehnei, M., Irtyshcheva, I., Khaustova, K. and Boiko, Y. (2017), "Modeling of strategic control system in the context of sustainable development of enterprise", Problems and Perspectives in Management, vol. 15, no. 3, pp. 212-223. doi: http://dx.doi.org/10.21511/ppm.15(3-1).2017.05

Suntsova, O. O. (2009), Mistcevi finansy [Local finances], Center for Education Literature, Kyiv, Ukraine, 488 p. Tarnai, V. (2015), "Budget of the local council in the conditions of decentralization", available at: http://eidos.org.ua/novyny/byudzhet-mistsevoji-rady-v-umovah-detsentralizatsiji/ (Accessed 20 October 2019)

Voitovych, T. B. (2012) "The main problems of local budget revenues in Ukraine and ways to overcome them", Strategic guidelines, available at: http://libfor.com/index.php?newsid=1202 (Accessed 20 October 2019)

Yevtushenko, N. M. (2015), “Formation of local budgets in the context of budget decentralization”, Economic Bulletin of the University, no. 27/1, pp. 162-168.

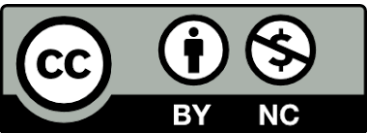

Цей твір ліцензовано на умовах Ліцензії Creative Commons «/з Зазначенням Авторства - Некомериійна 4.0 Міжнародна» (CC BY-NC 4.0). This is an open access journal and all published articles are licensed under a Creative Commons "Attribution-NonCommercial 4.0 International" (CC BY-NC 4.0). 